\title{
Examination of relationship between preservice chemistry teachers' preferences for creating constructivist-learning environment and sense of efficacy
}

\author{
Senar Temel ${ }^{1, *}$ \\ ${ }^{1}$ Hacettepe University, Department of Mathematics and Science Education, 06800, Beytepe, Ankara, \\ Turkey
}

\begin{abstract}
The aim of this study was to determine the relationship between preservice chemistry teachers' preferences for creating constructivistlearning environment and sense of efficacy. The study was conducted with 50 preservice chemistry teachers. Correlational research design was conducted to determine the relationship between the variables. Constructivist Learning Environment Survey (CLES) and Teachers' Sense of Efficacy Scale (TSES) were used as data collection tools. While CLES includes 30 items under five subscales, TSES includes 12 items under three subscales. Pearson Product-Moment Correlation Analysis was used to analyze obtained data. The results of the study revealed that there was a significance correlation between preservice chemistry teachers' preferences for creating constructivist-learning environment and sense of efficacy for total scores $(\mathrm{r}=.36, \mathrm{n}=50, \mathrm{p}<.05)$.
\end{abstract}

\section{Introduction}

Teacher sense of efficacy is an important component to develop teachers' efficaciousness in educational environments [1]. This concept is related to their belief in how students learn well and how they can influence their students in a learning environment [2]. Teachers with high self-efficacy tend to create better student outcomes because these teachers are more insistent in helping students with difficulties [3,4]. Teacher sense of efficacy is effective for teachers to create a supportive learning environment, to teach a subject and to provide discipline in the classroom [5]. As to attaining the educational objectives depends on the quality of classroom-learning environment [6]. In order to improve the quality of the classroom-learning environment, it was emphasized to prepare a learning environment in parallel with constructivist learning approach along with the reforms in our country [7]. The success of a programme based on constructivism is directly associated with the knowledge, skills, experience and beliefs of teachers who are expected to implement this programme [8]. In such an environment, which involves constructivist teaching, teachers invite students to be involved in decisions about their learning. Interactions between students and teachers are emphasized in a constructivist classroom. With the development of constructivism,

\footnotetext{
*Corresponding author: senarhacettepe@gmail.com
} 
teachers are able to create a classroom environment within students are able to become autonomous learners [9]. At this point, it was aimed to examine the relationship between pre-service teachers' preferences for constructivist-learning environment and sense of efficacy, which would be effective in creating such an environment. In addition, it is thought that the study may contribute to the literature in terms of the limited number of studies $[10,11,12,13,14]$ in which the relationship between these two variables is examined and in the absence of studies conducted with chemistry preservice teachers in particular in the literature.

\subsection{The aim of the study}

The aim of this study was to determine the relationship between preservice chemistry teachers' preferences for creating constructivist-learning environment and sense of efficacy.

\section{Method}

Correlational research design was conducted to determine the relationship between the variables of the study. This research design was used by researchers to describe and measure the degree of relationship between two or more variables or sets of scores [15].

\subsection{Study group}

The study was conducted with 50 preservice chemistry teachers. The study group was selected with convenience sampling method. Convenience sampling referred to as accidental sampling, basically involves including in the sample whoever happens to be available at the time [16]. A total of preservice chemistry teachers attending the Faculty of Education in a public university during the fall semester of the 2018-2019 academic year were participated voluntarily in the study. Of the preservice chemistry teachers, nine were male and 41 were female, age ranged from 18 to 53 (mean=22.04, $\mathrm{sd}=5.62$ ).

\subsection{Data collection tool}

The Constructivist Learning Environment Survey (CLES) developed by Taylor, Fraser, and Fisher [17] and adapted and translated into Turkish by Aydın, Boz, Sungur, and Çetin [18]. The survey was developed to assist researchers and teachers to assess the degree to which a particular classroom's environment is consistent with a constructivist epistemology, and to help teachers to reflect on their epistemological assumptions and reshape their teaching practice [19]. The CLES includes 30 items under five subscales named Learning about the World (LW), Learning about Science (LS), Learning to Speak out (LSO), Learning to Learn (LL), and Learning to Communicate (LC). The Cronbach's alpha coefficient was found as .87 as overall.

Teachers' Sense of Efficacy Scale (TSES) developed by Woolfolk Hoy [20] translated and adapted into Turkish by Çapa, Çakıroğlu, and Sarıkaya [21]. TSES includes 12 items under three subscales named Efficacy for instructional Strategies (EIS), Efficacy for Classroom Management (ECM), and Efficacy for Student Engagement (ESE). TSES was a 9-point Likert scale ranging from " 1 = nothing" to " $9=$ a great deal". The Cronbach's alpha coefficient for the entire scale was .93; for the subscale EIS was .86, for the subscale ECM was .84, and for the subscale ESE was .82.

\subsection{Analyses of the data}


Pearson product-moment correlation coefficients were calculated for determining the relationship between teachers' preferences for creating constructivist-learning environment and sense of efficacy.

\section{Findings}

The findings related to correlation analysis were given in Table 1.

Table 1. Findings of correlations analysis

\begin{tabular}{|c|c|c|c|c|c|}
\hline & & ECM & ESE & EIS & TSES \\
\hline \multirow{3}{*}{ LW } & Pearson Correlation & $.303^{*}$ & $.485^{* *}$ & $.314^{*}$ & $.417^{* *}$ \\
\cline { 2 - 6 } & Sig. (2-tailed) & .032 & .000 & .026 & .003 \\
\hline \multirow{3}{*}{ LS } & Pearson Correlation & .094 & $.386^{* *}$ & .131 & .226 \\
\cline { 2 - 6 } & Sig. (2-tailed) & .516 & .006 & .364 & .115 \\
\hline \multirow{2}{*}{ LSO } & Pearson Correlation & .222 & $.477^{* *}$ & $.320^{*}$ & $.383^{* *}$ \\
\cline { 2 - 6 } & Sig. (2-tailed) & .120 & .000 & .024 & .006 \\
\hline \multirow{3}{*}{ LL } & Pearson Correlation & -.130 & -.120 & -.097 & -.133 \\
\cline { 2 - 6 } & Sig. (2-tailed) & .367 & .405 & .501 & .356 \\
\hline \multirow{2}{*}{ LC } & Pearson Correlation & .034 & $.314^{*}$ & .195 & .200 \\
\cline { 2 - 6 } & Sig. (2-tailed) & .815 & .026 & .175 & .164 \\
\hline \multirow{2}{*}{ CLES } & Pearson Correlation & .159 & $.516^{* *}$ & $.283^{*}$ & $.357^{*}$ \\
\cline { 2 - 6 } & Sig. (2-tailed) & .270 & .000 & .047 & .011 \\
\hline
\end{tabular}

** Correlation is significant at the 0.01 level (2-tailed).

The results of the study revealed that there was a significance correlation between TSES and CLES for total scores $(\mathrm{r}=.36, \mathrm{n}=50, \mathrm{p}<.05)$. In addition, the significance correlations were determined between LW and ECM, LW and ESE, LW and EIS, LW and TSES, LS and ESE, LSO and ESE, LSO and EIS, LSO and TSES, LC and ESE, CLES and ESE, and finally CLES and EIS.

\section{Discussion and conclusions}

In the current research, the relationship between preservice chemistry teachers' preferences for creating constructivist-learning environment and sense of efficacy were examined utilizing correlational research design. According to the results of correlation analysis, there was a significance correlation between TSES and CLES for total scores $(r=.36, n=50$, $\mathrm{p}<.05$ ). In addition, the significance correlations were determined between LW and ECM, LW and ESE, LW and EIS, LW and TSES, LS and ESE, LSO and ESE, LSO and EIS, LSO and TSES, LC and ESE, CLES and ESE, and finally CLES and EIS. In some studies [10, $11,12]$ researchers determined that classroom teachers' self-efficacy related to implementing the constructivist approach was high. Ongowo, Indoshi, and Ayere [14] concluded that correlations between constructivist-learning environment variables and selfefficacy and active learning strategies are all positively statistically significant. Nie, Tan, Liau, Lau and Chua [13] found that there was a stronger correlation between teacher 
efficacy and student-centered constructivist instruction than the correlation between teacher efficacy and teacher-centered didactic instruction.

As a conclusion, constructivist approach based on student-centered approach in instruction. The role of teachers in creating such a classroom-learning environment adopted student-centered approach is quite high. As stated by Saçıc1 [22], the researchers supposed that teacher sense of efficacy might have major factor when they encountered with instructional innovations, which require adoption of constructivist instruction tasks in classroom teaching. According to Finson, Riggs, and Jesunathadas [23] teachers with high sense of efficacy tend to prefer more student-centered teaching, use more inquiry approaches. At this point, it is a promising result that the relationship between preservice chemistry teachers' preferences for creating constructivist-learning environment and sense of efficacy is revealed and this relationship is statically significant. The fact that pre-service chemistry teachers are more involved in tasks based on constructivist approach during their undergraduate education is so important in terms of adopting this approach more and enhancing the belief that they could prefer this approach in their classes and create studentcentered learning environments in the future.

In the current research, the relationship between the two variables was examined via data collection tools (CLES and TSES) conducted for once. In future longitudinal researches examining the diversity of preservice chemistry teachers' preferences for creating constructivist-learning environment and sense of efficacy during their teaching process could be conducted.

\section{References}

1. D. Pendergast, S. Garvis, J. Keogh, Aust. J. Teac. Educ. 36, 12 (2011)

2. A. B. Dellinger, J. J. Bobbett, D. F. Olivier, C. D. Ellett, Teach. Teac. Educ. 24, 3, (2008)

3. D. M. Podell, L. C. Soodak, J. Educ. Res. 86, 4, (1993)

4. L. C. Soodak, D. M. Podell, J. Spec. Educa. 27, 1, (1993)

5. A. Bandura, Self-efficacy: the exercise of control (New York: W, H, Freeman and Company 1997)

6. B. J. Fraser, Learn. Environ. Res. 4 (2001)

7. MONE Science and Technology Course Program (6th, 7th, and 8th Grades) (Ankara: National Ministry of Education Publications 2006)

8. I. Sönmez Öktem, Turk. Stud. Educ. Sci. 13/19, 1583-1594 (2018)

9. C. N. Che Ahmad, C. C. Wang, Y. Asmayati, A. Mohd, Procedia Soc Behav Sci. 191, (2015)

10. S. Çayak, M. A. E. Uni. J. Edu. Fac. 31 (2014)

11. S. Demir, F. Önen, F. Sahin, Fen bilgisi ögrretmen adaylarının yapılandırmacı yaklaşımı uygulamaya yönelik özyeterlilik inanç düzeylerinin belirlenmesi üzerine bir araştırma (X. Ulusal Fen Bilimleri ve Matematik Egitimi Kongresi, 2012)

12. E. Evrekli, F. Şaşmaz Ören, D. İnel, Öğretmen adaylarının yapılandırmacı yaklaşımı uygulamaya yönelik ozyeterliliklerinin cinsiyet, bölüm ve sinıf düzeyi değişkenleri açısından incelenmesi (I. Uluslararası Eğitimde Yeni Yönelimler ve Yansımaları Konferans1, 2010)

13. Y. Nie, G. H. Tan, A. Liau, S. Lau, B. L. Chua, Educ. Res. Policy Prac. 1 (2012)

14. R. O. Ongowo, C. F. Indoshi, M. A. Ayere, Glob. J. Interdiscip. Sch. Sci. 3, 4 (2014) 
15. J. W. Creswell, Educational research: planning, conducting, and evaluating quantitative and qualitative research (4th ed.) (Boston, MA: Pearson 2012)

16. L. R. Gay, P. Airasian, Educational research competencies for analysis and application (6th Edition) (Ohio: Merrill an Imprint of Prentice Hall 2000)

17. P. C. Taylor, B. J. Fraser, D. L. Int. J. Educ. Res. 27 (1997)

18. S. Aydın, Y. Boz, S. Sungur, G. Çetin, H.U. J. Educ. 42 (2012)

19. B. J. Fraser, Research on science teacher knowledge. In Abell, S. K \& Lederman, N.G. Handbook of Research on Science Education (pp.103-124) (New Jersey: Lawrence Erlbaum Associates 2007)

20. A. E. Woolfolk Hoy, W. K. Hoy, Instructional leadership: A research-based guide to learning in schools (Boston, MA: Allyn and Bacon (2009)

21. Y. Çapa, J. Çakıroğlu, H. Sarıkaya, Educ. Sci. 30, 74 (2005)

22. S. Saçıc1, The interrelation between pre-service science teachers' conceptions of teaching and learning, learning approaches and self-efficacy beliefs (Middle East Technical University, Master of Science 2013)

23. K. Finson, I. Riggs, J. Jesunathadas, The relationship of science teaching self efficacy and outcome expectancy to the draw-a-science-teacher-teaching checklist (Paper presented at the annual meeting of the Association for the Education of Teachers of Science, Austin, Texas 1999). 